\title{
Molecular characterization of a severe isolate of papaya ringspot virus in Mexico and its relationship with other isolates
}

\author{
Juan Carlos Noa-Carrazana · Diego González-de-León • \\ Laura Silva-Rosales
}

Published online: 17 May 2007

(C) Springer Science+Business Media, LLC 2007

\section{Erratum to: Virus Genes}

DOI: 10.1007/s11262-006-0039-y

In the online and print version of the original article, the corresponding author's previous email address is no longer available. The updated email address is: lsilva@ira.cinvestav.mx

The online version of the original article can be found at http://dx.doi.org/10.1007/s11262-006-0039-y

J. C. Noa-Carrazana $\cdot$ L. Silva-Rosales $(\bowtie)$

Cinvestav Campus Guanajuato, Apdo Postal 629, Irapuato

Gto 36500, Mexico

e-mail: 1silva@ira.cinvestav.mx

D. González-de-León

Paseo del Atardecer 360, Col Villas de Irapuato, Irapuato

Gto 36670, Mexico

J. C. Noa-Carrazana

Laboratorio de Biotecnología y Ecología Aplicada, Universidad

Veracruzana, Circuito Los Lagos S/N, Zona Universitaria

Campus Sur, Apdo. Postal 250, Xalapa, Veracruz 91001,

Mexico 